\title{
Cuba and the Caribbean Basin: from pariah to partner?
}

\author{
by H. Michael Erisman
}

\begin{abstract}
Three books examined Cuba's relationships with other nations and economic diversification-development alliances that shaped the country's role in Caribbean Basin affairs. Kenneth N. Skoug Jr presented his experiences as the State Dept's coordinator of Cuban affairs from 1982 to 1988, emphasizing Cuba's developmental coalition building efforts. Rodriguez-Beruff and Muniz's work focused on security and policy concerns in the post-Cold War Caribbean Basin while Tulchin, Serbin and Hernandez's book deals gave a general discussion on the area's trends and problems.
\end{abstract}

\section{@ COPYRIGHT 1998 Transaction Publishers, Inc.}

Cuba's role in the Caribbean Basin and its relationships with individual countries therein has, over the course of the Cuban revolution, conformed to the general outlines of its larger Latin American policies.(1) Havana's priorities over time with regard to both the Caribbean Basin and the Western Hemisphere as a whole can, for purposes of simplicity, be summarized as follows.(2)

During the 1960s, emphasis was placed on the revolution's obligation to put into practice the principle of proletarian internationalism, which translated into support for the armed struggles of various insurgent movements. Although such solidarity saw its heyday in the 1960s, some instances of reinvigoration occurred in the late 1970s and early 1980s (that is, in Sandinista Nicaragua, in New Jewel Grenada, and to a somewhat lesser extent, in war-torn El Salvador). Those guerrilla operations of the 1960s were first significantly pursued in the island Caribbean (for example, against the Trujillo regime in the Dominican Republic) and in Central America.

Beginning in the early 1970 s and continuing through the 1980 s, attention shifted to attempts to normalize state (that is, diplomatic-political) relations with a fairly broad spectrum of hemispheric countries. The first major successes along these lines involved CARICOM countries, with Barbados, Guyana, Jamaica, and Trinidad and Tobago all establishing ties in 1972.

The primary concerns now are to expand both the scope and the depth of Havana's economic relations with hemispheric countries and to participate in efforts aimed at developmental South-South coalition building. This campaign began in earnest in the early 1990s and continues to dominate Cuba's Caribbean and Latin American agendas. Once again, the Caribbean Basin has emerged as a nerve center of Cuban activity, as indicated by Havana's overtures to achieve membership in economic coalitions, which have focused on two regional organizations, the Caribbean Community and Common Market (CARICOM) and the Association of Caribbean States (ACS).
Note how these three major phases of Cuban policy suggest a progression from pariah to partner within the hemispheric community of nations. Havana's initial priority of overthrowing the existing political-economic order in countries via guerrilla insurgencies gave way first to efforts at diplomatic reconciliation, and more recently to attempts to enter into ambitious multilateral joint ventures in economic-political cooperation.

This review will focus primarily on the economic diversification-developmental partnership stage summarized above, evaluating the books at hand in terms of their contributions to understanding this aspect of Cuba's evolving role in Caribbean Basin affairs.

The concept of South-South developmental coalition building involves two key dimensions. The first is the establishment of institutionalized, multilateral economic relations with other developing countries, wherein the participant - in this case, Cuba - enjoys some preferences, the most common relating to trade (although the equation might also include such benefits as financial credits, grants, investment prerogatives, or technical assistance). These arrangements should be "institutionalized" in the sense of being, at a minimum, incorporated into a formal, fairly long-term accord (that is, a multilateral treaty) and ideally having a formal administrative structure (for example, a commission or a secretariat) to oversee and coordinate implementation of the accord's provisions. In short, such coalition building entails some movement toward mutually beneficial economic integration with a clearly defined (and limited) set of partners. Among the most frequent first step taken is membership in either a free trade area or a common market.

The second key element in this scenario concerns the enhancement of (collective) South-North bargaining power. The basic idea here is to use South-South coalition building as a mechanism for pooling the bargaining power of developing countries in pursuit of a common agenda, thereby putting them in a much stronger position to negotiate more advantageous developmental arrangements with the industrialized centers of economic power in the world (that is, individual nations like the United States or larger groupings such as the European 


\section{Cuba and the Caribbean Basin: from pariah to partner?}

Community and NAFTA). Cuba's pursuit of such a coalition-building strategy in the Caribbean Basin has concentrated heavily on CARICOM and the ACS.

Since roughly late 1989 and early 1990, Havana has made a major effort to enlarge and deepen its relations with the CARICOM nations. This process began to gain momentum in late 1990 when, in response both to Cuban overtures and to CARICOM's desire to boost participation in the organization, the CARICOM heads of state decided, at their 11th summit conference (held in August 1990, in Jamaica), to launch serious discussions with Havana regarding the possibilities for increased economic cooperation. After overcoming some initial complications, this process began to bear fruit at the 13th CARICOM summit conference (June 1992, Trinidad). While Havana's request for official observer status was not approved (largely, it was reported, because of intense counterlobbying by the United States), CARICOM did vote to establish a joint commission to explore the prospects for greater CARICOM-Cuban cooperation in the areas of trade, developmental programs, and cultural exchanges. A formal agreement setting up the commission was concluded at the 14th CARICOM summit (July 1993, The Bahamas).

Beyond this point, however, Havana's efforts to achieve official standing in the organization have proven fruitless. Its repeated requests for status as a CARICOM observer nation, for example, have not been granted. Likewise, its campaign to conclude a free trade agreement with the group was rebuffed (at least for the time being) in August 1996, the main explanation being that such a move might unnecessarily antagonize Washington during the volatile U.S. presidential season. But this reticence continued even after Bill Clinton was reelected, as illustrated by CARICOM's failure to consider the question of Cuban membership at a February 1997 meeting in Antigua and its rejection once again of Havana's proposed trade agreement at its July 1997 summit meeting in Montego Bay, Jamaica.

The ACS proved much more receptive to Cuba's coalition-building aspirations. The ACS was first proposed in 1991 by the blue-ribbon West Indian Commission (headed by Shridath Ramphal of Guyana) that had been established in 1989 to provide CARICOM leaders with ideas about future directions for the organization.

According to Andres Serbin, the primary objectives of the ACS were envisaged as follows:

* To maximize regional trade and those economies of scale needed to achieve insertion into the international economic system through trade liberalization
* To optimize the region's bargaining power with third parties (given the present decline in strategic importance) through the forging of strategic regional alliances based on identification of common interests

* To move toward various forms of cooperation (and eventual integration) by forging consensus on matters of common interest and consolidating a regional identity, based on a common cultural and social fabric, that will overcome existing divisions and heterogeneity and benefit the population of the entire region (Serbin 1994, 64)

CARICOM endorsed the ACS concept at its 14th summit (The Bahamas, July 1993). Subsequently, based on this commitment, a joint CARICOM-Group of Three (Mexico, Venezuela, and Colombia) conference was convened in Trinidad (October 1993) that issued the Port-of-Spain Declaration, wherein an official call was issued for the creation of the ACS (with Cuba being explicitly designated as eligible for membership). The treaty formally launching the organization, with Cuba participating as a charter member, was signed on July 24, 1994, in Cartagena, Colombia.

Because Kenneth Skoug is writing about his experiences as the State Department's coordinator of Cuban affairs from 1982 to 1988, his frame of reference does not include the post-Cold War phase of Cuba's foreign relations that emphasizes economic diversification and coalition building. Consequently, he tends to reflect, admittedly in a somewhat more muted fashion, the Reagan administration's view of Havana as a pariah in the Caribbean Basin and elsewhere. The more extreme elements in the Reaganite camp were not, of course, content merely to ostracize Cuba. Instead, demonization was their forte, with Havana portrayed as an unscrupulous surrogate of the Kremlin that was at the root of practically all the instability, violence, and security threats in the Caribbean Basin (especially Central America). As such, Cuba (along with Sandinista Nicaragua) became one of the Reagan Doctrine's main targets in the Western Hemisphere. Indeed, it was during Reagan's watch that the Grenada invasion produced the only direct military confrontation between the regular armed forces of the United States and revolutionary Cuba.

Unfortunately, Skoug's book ignores, for the most part, the larger drama of this confrontation between the alleged pariah of the Caribbean and the Colossus of the North, concentrating instead on the often tedious details of how the two parties maneuvered around and negotiated over two fairly narrow concerns: Cuban migration to the United States (both legal and illegal) and Washington's establishment of Radio Marti. Almost the entire book is devoted to exploring the minutiae of these two questions. 


\section{Cuba and the Caribbean Basin: from pariah to partner?}

Lost in the process are such larger issues as the following.

* Cuba and the Reagan Doctrine. Although not absolutely certain that it was never mentioned in passing, this reviewer could not find a single reference to the Reagan Doctrine in the entire text. Certainly it did not merit an entry in the book's index.

* Havana's involvement in Central America. The only separate section on Central America consists of exactly 26 lines on pages 43-44. Given the immense amount of time, energy, resources, and political capital that the Reagan administration devoted to the region, and its contention that Cuban actions were pivotal in helping to create crises there, one would think that the topic deserves a bit more attention than 26 lines.

* The U.S.-Cuban (military) confrontation in Grenada. This subject fares somewhat better than Central America, receiving $71 / 2$ (out of a total 213) pages of consideration, but it still seems to be shortchanged in light of the controversy that swirled around the incident.

Such oversights render the Skoug book rather disappointing. It reads more like the mundane memoirs of a petty bureaucrat than an analysis or defense of Reaganite policy toward Cuba by a person who stood at, or at least very near, the center of the action.

The main thrust of the Rodriguez-Beruff-Garcia Muniz volume is to explore the shifting conceptualization of security and the policy implications thereof with respect to the post-Cold War Caribbean Basin. The editors' two main theses are designed to provide a broad conceptual framework for the contributors. The first is that Washington now defines its Caribbean security interests primarily in terms of migration and drug problems, with environmental questions occasionally entering the picture. The second is that today, countries in the Caribbean Basin are most concerned about economic security, rather than the political-military threats emanating from superpower competition for regional influence that topped their agendas during the height of the Cold War.

It may, however, be questionable whether Cuba's situation fits very neatly into this post-Cold War paradigm, for an argument can be made that in reality, the Cold War continues (with some modifications) between Washington and Havana. A Cuban Foreign Ministry official put forth this position in an interview with the reviewer during a September 1997 visit to the island. His analysis can be summarized as follows.

As far as Havana is concerned, the U.S. redefinition of security threats in the Caribbean (that is, migration and drugs) can be seen as a mechanism that provides Washington with a rationale, bolstered by its charges of human rights violations and antidemocratic values, to maintain its Cold War hostility toward Cuba. Such a new justification became necessary, of course, when it could no longer be argued that Havana had close ties to the Soviet bloc that represented a political-military threat to the Caribbean region and to U.S. security interests therein. This reconstituted belligerence takes the form of intensified economic warfare against Cuba, as exemplified by the Torricelli and Helms-Burton laws. The goals of this newly rationalized policy are straight out of the Cold War: to destroy Cuba's government and to eradicate the revolution.

Approached from this perspective, Havana's current emphases on expanding its economic relations and engaging in developmental coalition building are inextricably linked with traditional security concerns; specifically, dealing with U.S. policies that are seen as threatening to the country's sovereignty and independence. Thus, in contrast to the editors here, the Fidelistas do not feel that the key U.S.-Cuban security issues have been radically redefined by Washington in response to a dramatically new international environment, but rather that they have, at most, only been reconfigured somewhat in an ongoing Cold War context.

Of the two chapters in the Beruff-Muniz book that deal specifically with Cuban affairs, the contribution by Isabel Jaramillo Edwards of the Center for the Study of the Americas (Centro des Estudios sobre America, CEA) in Havana is much more closely attuned to the special characteristics of Havana's situation, particularly the complex interplay between the traditional geopolitical (that is, political-military) and the contemporary geoeconomic dimensions of the island's security agenda. The broad overview approach that her analysis employs is quite appropriate, but in the process Caribbean Basin relations do not receive as much attention as might be expected in a book devoted to that topic. The most glaring omission here is the absence of any discussion of Cuban developmental coalition-building initiatives in the region. Compensating somewhat for this oversight is the extended and very informative section on "The War of All the People" concept as the keystone of Cuba's contemporary military defense strategy.

Anthony Maingot's chapter can be characterized as dissonant in the sense that it never really comes directly to grips with the book's core theme of security. Instead, Maingot seeks to shift the focus from straightforward security concerns to the general dynamics of negotiating a normalization of U.S.-Cuban relations, rationalizing this move on the basis that "diplomacy is fundamentally a 


\section{Cuba and the Caribbean Basin: from pariah to partner?}

strategic game" (p. 144). Perhaps; but Maingot's perception of that game is sorely lacking in any serious attention to issues raised by the editors (for example, migration, drugs, economic development) or by the Cubans (the sovereignty-threatening implications of policies based on the Torricelli and Helms-Burton laws).

Instead of dealing with these thorny questions, Maingot essentially embraces the conventional U.S. government position that the future course of relations with Havana will revolve around Cuba's willingness to accede to Washington's demands regarding its human rights performance, democratic multiparty elections (which, says the Helms-Burton law, will not be acceptable if won by Fidel or Raul Castro), and the creation of a free market economy. The problem, of course, is that the United States has, in one form or another, long tried to impose its will on revolutionary Cuba and has always failed. This approach has not, in other words, produced good policy, and Maingot should know that its analytical implications are similarly flawed.

The last half of the Tulchin collection deals specifically with Havana's evolving role in the Caribbean, while the first part presents a more general discussion of the area's trends and problems. The seven chapters constituting the book's Cuba block provide, for the most part, a solid, comprehensive survey of the topic. The only exception is Jorge Duany's discussion of Caribbean migration, which focuses more on the larger regional phenomenon than on the specifics of its Cuban dimension.

The Cuban perspective is presented by Rafael Hernandez (who at the time of writing his contribution was affiliated with the CEA) and Julio Carranza Valdes (a professor with the University of Havana's Center for the Study of the Cuban Economy, CEEC). Hernandez explores Havana's view of and approach to security concerns in an environment dominated by ongoing hostility from Washington. In the process, he develops in much greater detail the continuing Cold War thesis summarized previously. Carranza provides a fascinating and extremely thoughtful discussion of the economic reforms (especially in the domestic sphere) that he feels are necessary to facilitate Cuba's accommodation to a market-driven international economic order, his basic desire being to maintain the revolutionary essence of Cuban society while recognizing that it may be necessary to move "from the [traditional] socialist model to a new model" (p. 205).(3)

The key point of consensus emerging from the three chapters that examine the Cuban question primarily from a Caribbean viewpoint (written by Anthony Bryan, Jacqueline Braveboy-Wagner, and Geraldo Gonzalez Nunez) is that CARICOM as an organization and some of its more adventurous members, such as Trinidad and Tobago, are very likely to push forward in exploring options to expand cooperative relations with Havana, particularly in the areas of trade and investment. But all the analyses caution that any initiatives undertaken will almost surely proceed quite cautiously, given the extensive influence the United States exerts in the region. NAFTA is frequently mentioned as a potential vehicle for Washington to drive a wedge between the CARICOM countries and Havana.

Considering that many Western European states have long been involved in Caribbean affairs, Wolf Grabendorff explores their reactions to the Cuban dimension of contemporary regional developments. His basic conclusion is that while ideological disagreements (for example, regarding human rights) will continue to complicate European-Cuban relations, most members of the European Community can be expected to pursue a pragmatic "policy without illusions" (p. 239) toward Havana that is inspired more by commercial than by political considerations.

The books reviewed here, along with the larger body of literature on Cuba's foreign relations, raise serious questions about the rhetoric coming out of official Washington. If an observer were to look no further than these self-serving proclamations, the resulting portrait would be one of Havana as a socialist dinosaur completely isolated from its Caribbean neighbors and the rest of the world community. But once one moves beyond the myopia of the Beltway and takes, as do most of the analysts surveyed here, an objective look at the situation, Havana's evolving status in the Caribbean Basin and elsewhere would appear to lean much more toward the pole of partner than that of pariah.

\section{NOTES}

1. The Caribbean Basin is, for purposes of this review, defined as basically encompassing the member states of CARICOM and the Central American nations. While this conceptualization is more restrictive than normal (for example, in the sense that countries like Venezuela and Colombia are frequently included in a listing of Caribbean Basin states), it reflects the essential geographical scope of the books being reviewed.

2. It is interesting that the United States and Cuba seem to share a tendency to "test" policy initiatives in regions of close proximity before applying them on a broader international scale. In Washington's case, Latin America frequently seems to have been employed in such a "laboratory" capacity. Some examples of hemispheric policies serving as forerunners are the Good Neighbor 


\section{Cuba and the Caribbean Basin: from pariah to partner?}

Policy, which can be seen as an early manifestation of later economic aid programs (for example, the Marshall Plan) that sought politically to stabilize countries and regions; the 1947 Rio treaty, which was the first U.S. step in building a complex post-World War II military alliance system; and the 1954 CIA intervention in Guatemala, which signaled a growing interest on Washington's part in unconventional warfare operations as an instrument of foreign policy. Similarly, Cuba has often appeared to use the Caribbean Basin as the venue for first implementing ideas that have later become part of its larger Latin American agenda.

3. These reform ideas are developed and explained more fully in Carranza Valdes et al. 1996.

\section{REFERENCES}

Carranza Valdes, Julio, Luis Gutierrez Urdaneta, and Pedro Monreal Gonzalez. 1996. Cuba: Restructuring the Economy - A Contribution to the Debate. Translated by Ruth Pearson. London: Institute of Latin American Studies, University of London.

Serbin, Andres. 1994. Towards an Association of Caribbean States: Raising Some Awkward Questions. Journal of Interamerican Studies and World Affairs 36, 4 (Winter): 61-90. 